\title{
Confocal Laser Microlaryngoscopy
}

National Cancer Institute

\section{Source}

National Cancer Institute. Confocal Laser Microlaryngoscopy. NCI Thesaurus. Code C122390.

An endoscopic modality using confocal laser endomicroscopy to produce high magnification and resolution images during the study of the laryngeal tissues. 